\title{
Pengembangan Media Stagame Berbasis PC Game Untuk Meningkatkan Kemampuan Pemecahan Masalah Materi Statistika
}

\section{Rina Narisa Zuliani ${ }^{1 *}$, Henny Dewi Koeswanti ${ }^{1}$}

${ }^{1}$ Prodi Pendidikan Guru Sekolah Dasar, Universitas Kristen Satya Wacana,

Salatiga, Indonesia,

*e-mail: zuliani88@gmail.com

\begin{abstract}
Abstrak
Penelitian ini bertujuan menguji media pembelajaran berbasis PC Game untuk pembelajaran matematika materi statistika dilaksanakan. Media yang dikembangkan yaitu Stagame merupakan akronim dari kata Statistika Game. Metode yang digunakan dalam penelitian ini model pengembangan ASSURE yang terdiri dari 6 tahapan yaitu (1) Analyze Learner;(2) State Objective; (3) Select Methods, Media, and Materials; (4) Utilize Media and Materials; (5) Required Learner Participation; dan (6) Evaluate and revise. Data penelitian dikumpulkan menggunakan kuesioner yang digunakan untuk mengukur validitas media dari aspek isi dan aspek media. Digunakan 1 orang pakar materi dan pakar media. Data dianalisis secara deskriptif. Hasil pengujian menunjukkan bahwa validitas stagame dari aspek materi adalah $78 \%$ dan validitas dari aspek media adalah $81,5 \%$ dengan kategori valid.
\end{abstract}

Kata kunci: media statistika game, pembelajaran matematika

\begin{abstract}
This research and development also aims to develop a PC game-based learning media for learning mathematics with statistical materials. The media developed, namely STAGAME, is an acronym for the word Game Statistics. The method used in this research is $R$ \& D with the ASSURE development model which consists of 6 stages, namely (1) Analyze Learner, (2) State Objective; (3) Select Methods, Media, and Materials; (4) Utilize Media and Materials; (5) Required Learner Participation; and (6) Evaluate and revise. The validity of the product was obtained by testing material and media experts. development of PC Game-based learning media to improve problemsolving abilities on flat-shape materials in the Very Appropriate category. Thus, the media in the Very Appropriate category can be used in learning in grade 4 of Elementary School. The feasibility of the media is seen from the expert validation test, namely the material and media. The results of the validation of the material expert 7 (8\%) and media (81.5) so that it can be said that the learning media is valid.
\end{abstract}

Keywords: game statistics media, learning mathematics

\section{Pendahuluan}

Teknologi informasi dan komunikasi (TIK) memiliki pengaruh yang signifikan terhadap perkembangan berbagai sektor baik sektor ekonomi, politik, sosial, budaya, kesehatan, termasuk pendidikan. TIK memang memberikan kemudahan, kepraktiksan, dan kenyamanan dalam berbagai sektor tersebut (Utami, 2015: 17). Pendidikan merupakan sektor yang terpengaruh oleh perkembangan TIK dan diharapkan bisa digunakan secara positif dalam pembelajaran. Komponen pembelajaran yang terdampak oleh perkembangan TIK adalah media pembelajaran. Media pembelajaran bahan atau alat yang digunakan mempermudah terjadinya penyampaian informasi pembelajaran dari guru ke siswa. Media pembelajaran dapat menyampaikan atau mengirim pesan dari suatu sumber (pengirim) ke penerima dengan tujuan merangsang pikiran, perasaan, perhatian dan minat siswa sehingga pembelajaran menjadi efektif dan efisien (Prihatin, 2008; Sadiman, Arief., 2006). Media pembelajaran juga merupakan hal yang dapat membantu menyebarkan informasi dari berbagai sumber belajar, sehingga tercipta lingkungan untuk belajar yang menyenangkan juga tercipta proses dari pembelajaran yang efektif dan juga efisien (Azhar, 2011). Seirama dengan pembelajaran saat ini, guru 
paksa untuk menggunakan TIK dalam pembelajaran.

Materi statistika merupakan materi yang lebih dikenal dengan aktivitas perhitungan. Sehingga tidak sedikit pembelajar yang merasa ketakutan ketika mendengar kata statistika karena dianggap ilmu yang sulit dan ilmu yang rumit dipelajari. Ditemukan beberapa kesulitan peserta didik dalam mengikuti pembahasan materi statistika yaitu faktor internal seperti kurangnya pemahaman awal tentang statistika, 2) motivasi intrinsik pembelajar karena menggap statistika adalah hal yang sulit. Faktor eksternal seperti kurangnya media pembelajaran berbasis TIK, alat peraga, belum tepatnya pemilihan strategi pembelajaran. Peneliti lainnya juga menemukan bahwa kesulitan peserta didik dalam mengikuti pembelajaran statistika adalah lemahnya kemampuan dasar (kemampuan memahami), terbatas media, lemahnya motivasi dan kemampuan belajar (Firmansyah, 2017; Maryati, 2017; Nurdianto et al., 2020). Kesulitan-kesulitan yang dialami peserta didik terlah berdampak terhadap penurunan hasil belajar peserta didik. Jika ini tetap dibiarkan mata peserta didik tidak akan memperoleh pengetahuan atau keterampilan setelah mengikuti pembelajaran statistika. Dari berbagai hambatan yang ada dalam pembelajaran maka dalam penelitian ini hanya difokuskan untuk mengatasi masalah eksternal pembelajaran yaitu masih terbatasnya media pembelajaran berbasis TIK untuk materi statistika. Fokus masalah ini dipilih karena media pembelajaran memiliki peran stategis dalam membantu peserta didik mengatasi kesulitan internal seperti motivasi dan kemampun belajar karena media mampu mengubah materi abstrak menjadi konkret.

Jenis media yang dikembangkan adalalag game. Game adalah jenis media yang termasuk pada kelompok media audio-visual. Game sendiri berasal dari kata bahasa Inggris yang berarti "permainan". Permainan merupakan bagian tak terpisahkan dari kehidupan sehari-hari anak. Permainan tertentu dapat dimainkan menurut aturan tertentu, sehingga biasanya ada pemenang dan ada yang kalah. Game mampu memberikan lingkungan melatih kecepatan, keteapan, dan kemampuan untuk berkerjasama memecahkan masalah (Beck, 2007). Statistika game atau yang sering disebut dengan stagame merupakan sebuah bentuk penyajian materi pembelajaran yang disusun secara sistematis dalam suatu bentuk game yang disajikan secara elektronik dan dapat diakses dimanapun dan kapanpun. Stagame dikembangkan dan diisi dengan berbagai materi yang dibutuhkan dalam pembelajaran, pada penelitian kali ini stagame menggunakan materi pengolahan data dan diagram. Hasil penelitian menunjukkan bahwa game memberikan suasana yang menyenangkan kepada peserta didik karena menyajikan suasana permainan. Rasa senang yang ditimbulkan memberikan efek positif terhadap motivasi siswa sehingga berdampak terhadap peningkatan outcome pembelajaran (Awan et al., 2019; Perini et al., 2018). Pengoperasian game tidak bisa terlepas dari perangkat komputer maupun smartphone. Peserta didik dapat belajar kapanpun dan dimanapun melalui telepon pintar yang mereka bawa. Stagame dapat diinstal pada smartphone peserta didik sehingga ini akan sangat memfasilitasi mereka untuk belajar secara fleksibe. Hasil-hasil penelitian juga menunjukkan bahwa Pembelajaran yang menggunakan smartphone dampak positif bagi peserta didik dan peserta didik dapat lebih mudah memahami materi (Novianto et al., 2015; Prayudi et al., 2015). Dengan demikian, tujuan dalam penelitian ini adalah mengembangkan game pada statistika yang valid dari dari aspek isi dan aspek media pembelajaran.

\section{Metode}

Penelitian ini adalah jenis penelitian pengembangan Research and Development (R\&D). Game dikembangkan menggunakan model ASSURE. Model ASSURE yang tersusun dari 6 tahapan yaitu Analyze Learner; State Standards and Objectives; Select Strategies, Technology, Media, and Materials; Utilize Technology, Media and Materials; Require Learner Parcipation; Evaluate and Revise. Tahapan dari ASSURE dapat dijadikan sebagai petunjuk dan membantu dalam merencanakan, mengidentifikasi, menentukan tujuan, memilih metode dan bahan, serta evaluasi (Smaldino et al., 2008). Model ASSURE dapat divisualisasikan pada Gambar 1. 


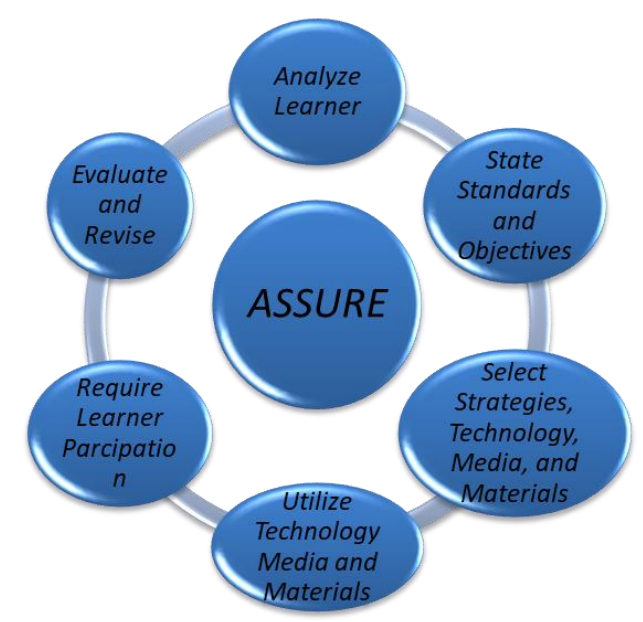

Gambar 1. Sintaks dari penelitian model ASSURE

Penelitian ini dilakukan 4 SD Negeri Dukuh 05. Subjek uji coba pada penelitian ini adalah 1 orang ahli isi dan 1 orang ahli media pembelajaran. Metode pengumpulan data dalam penelitian ini menggunakan metode angket. Angket digunakan untuk menilai validitas game dari aspek isi dan media pembelajaran. Butir angket aspek materi terjasi pada Tabel 1 dan aspek media pada Tabel 2.

Tabel 1. Instrumen Validitas Aspek Materi

\begin{tabular}{|c|c|c|}
\hline No & $\begin{array}{l}\text { Aspek yang } \\
\text { Dinilai }\end{array}$ & Pernyataan \\
\hline 1. & \multirow{7}{*}{ Aspek Materi } & Kesesuaian dengan kurikulum sekolah dasar \\
\hline 2. & & $\begin{array}{l}\text { Kesesuaian materi dengan kompetensi inti }(\mathrm{KI}) \text { dan kompetensi } \\
\text { dasar }(\mathrm{KD})\end{array}$ \\
\hline 3. & & Kebenaran konsep \\
\hline 4. & & Kemutakhiran materi \\
\hline 5. & & Urutan penyajian materi \\
\hline 6. & & Kesesuaian contoh yang diberikan \\
\hline 7. & & Tujuan pembelajaran \\
\hline 8. & \multirow{4}{*}{$\begin{array}{l}\text { Aspek } \\
\text { Pembelajaran }\end{array}$} & Motivasi \\
\hline 9. & & Rangkuman \\
\hline 10. & & Kejelasan indikator pembelajaran \\
\hline $\begin{array}{l}11 . \\
12 .\end{array}$ & & $\begin{array}{l}\text { Pemberian latihan } \\
\text { Kesesuaian gambar, video yang diberikan untuk memperjelas } \\
\text { materi }\end{array}$ \\
\hline 13. & \multirow{5}{*}{$\begin{array}{c}\text { Aspek } \\
\text { Kebahasaan }\end{array}$} & Kesesuaian bahasa dengan tingkat berfikir siswa \\
\hline 14. & & Kelugasan bahasa \\
\hline 15. & & Ketepatan istilah \\
\hline 16. & & Ketepatan bahasa dan ejaan \\
\hline 17. & & Kemampuan membangkitkan rasa ingin tahu siswa \\
\hline \multicolumn{3}{|r|}{ Tabel 2 Instrumen Validitas Aspek Media } \\
\hline No & $\begin{array}{l}\text { Aspek yang } \\
\text { Dinilai }\end{array}$ & Pernyataan \\
\hline 1. & \multirow{3}{*}{ Pemograman } & Kesesuaian menu sajian dalam media \\
\hline 2. & & Kejelasan memberikan petunjuk penggunaan media \\
\hline 3. & & Kesesuaian kolom respon peserta didik dalam media \\
\hline $\begin{array}{l}4 . \\
5\end{array}$ & \multirow{2}{*}{ Tampilan } & Kesesuaian jenis huruf yang digunakan \\
\hline 0. & & Kesesuaian ukuran huruf yang digunakan \\
\hline
\end{tabular}




\begin{tabular}{cll}
\hline No & $\begin{array}{c}\text { Aspek yang } \\
\text { Dinilai }\end{array}$ & \multicolumn{1}{c}{ Pernyataan } \\
\hline 6. & & Kesesuaian warna huruf dengan background yang digunakan \\
7. & Kesesuaian penggunaan jarak antar komponen dalam media \\
8. & Kesesuaian jangkauan keterbacaan teks \\
9. & Kesesuaian video dengan materi pembelajaran \\
10. & Kesesuaian durasi/ waktu pemutaran video dalam \\
& pembelajaran \\
11. & Kesesuaian ukuran layar video dalam media \\
12. & Kesesuaian gambar dengan materi pembelajaran \\
13. & Kesesuaian ukuran gambar dalam media pembelajaran \\
14. & Kesesuaian tata letak komponen-komponen dalam media \\
15. & Kejelasan tombol navigasi dalam media \\
16. & Daya guna tombol navigasi dalam media \\
17. & Kesesuaian warna background dengan gambar yang ada di \\
18. & media \\
19. & Kesesuaian warna background dengan tulisan yang ada di \\
20. & Kedia \\
21. & Keterkaitan penyajian antar halaman \\
22. & Keefektifan kalimat dalam media \\
23. & Kebakuan istilah dalam kalimat/ kata dalam media \\
24. & Kesesuaian dengan tingkat perkembangan emosional \\
25. & Keserta didik \\
26. & Kebakuan kalimat dalam media \\
\hline & & Kejelasan aturan penggunaan media \\
\hline & & Konsistensi penggunaan aturan media \\
\hline
\end{tabular}

Metode analisis data dalam penelitian ini adalah metode deskriptif kualitatif dan metode deskriptif kuantitatif. Deskriptif kualitatif digunakan untuk menganalisa komentar atau pendapat para ahli dan sekaligus dijadikan acuan untuk merevisi media game sedangkan deskriptif kuantitatif digunakan untuk menghitung skor yang diperoleh dari para ahli. Skor yang telah diubah menjadi bentuk persen selanjutnya dikonversi menggunakan penilaian acuan patokan skala lima seperti tersaji pada Tabel 1.

Tabel 1. Kriteria Kelayakan LKPD

\begin{tabular}{ccccc}
\hline No & Persentase Penguasaan & $\begin{array}{c}\text { Nilai } \\
\text { Angka }\end{array}$ & Nilai huruf & Predikat \\
\hline 1 & $90-100$ & 4 & A & Sangat Baik \\
2 & $80-89$ & 3 & B & Baik \\
3 & $65-79$ & 2 & C & Cukup \\
4 & $55-64$ & 1 & D & Kurang \\
5 & $0-54$ & 0 & E & Sangat Kurang \\
\hline & & & & Sumber: (Agung, 2014)
\end{tabular}

\section{Hasil dan Pembahasan}

Hasil pengembangan dijelaskan sesuai dengan model ASSURE. Adapun hasil dari setiap tahapan sebagai berikut. Pertama, Menganalisis Karakteristik Siswa (Analyze Learner). Salah karakteristik yang dianalisis adalah gaya belajar dan siswa dominan memiliki gaya belajar visual dan auditori. Kedua, dilakukan penetapan tujuan pembelajaran (State Standards and Objectives). Sebelum merumuskan tujuan pembelajaran akan dilakukan analisis Kurikulum 2013 terlebih dahulu. Analisis Kurikulum 2013 ini meliputi Kompetensi Inti (KI), Kompetensi Dasar (KD), Buku Siswa dan Buku Guru revisi 2017. Tujuan pembelajaran yang baik hendaknya mengandung komponen 
$A B C D$ yaitu singkatan dari Audience (pendengar), Behavior (tingkah laku), Condition (kondisi), dan Degree (perbandingan). Kata kerja operasional dalam rumusan tujuan mengacu pada Kurikulum 2013 dari $\mathrm{C} 1$ hingga C6. Perumusan tujuan pembelajaran tidak menggunakan lebih dari satu kata kerja operasional. Hal ini berarti aktivitas yang dilakukan siswa cukup satu kegiatan sehingga pembelajaran lebih optimal. Perumusan ini dilakukan untuk mempermudah melakukan pengembangan media pembelajaran yang sesuai dengan tujuan pembelajaran. Ketiga, memilih strategi, teknologi, media, dan materi. Pemilihan metode disesuaikan dengan gaya belajar siswanya. Metode yang akan digunakan yaitu ceramah, diskusi, simulasi, penugasan, dan tanya jawab. Teknologi yang digunakan dalam penelitian ini adalah laptop atau komputer dan smartphone. Jenis media pembelajaran yang akan dikembangkan berbasis media audio-visual yang berjenis audiovisual diam. Media yang akan dibuat termasuk dalam jenis $P C$ game. Selain itu, game akan menggunakan genre Action Adventure. Genre Action Adventure adalah yaitu game berupa petualangan salah seorang karakter yang penuh dengan penuh aksi yang akan terus ada hingga game tersebut tamat. Selain memilih media yang akan digunakan juga telah ditetmukan materi yang dimuat dalam game yaitu materi statistika kelas 4 sekolah dasar meliputi pengolahan data dan diagram. Keempat, Menghasilkan Bahan Ajar atau media pembelajaran. Pada penelitian ini dilakukan pengembangan media baru game. Pada tahap ini dilakukan penentuan format media, menentukan desain awal media, mengembangkan media, menyusunan instrumen penilaian media yang digunakan untuk menilai kualitas media yang dikembangkan, memvalidasikan media dan merevisi media berdasarkan kritik dan saran. Kelima, memanfaatkan teknologi, media, dan bahan (Utilize Technology Media and Materials). Tahap ini media akan digunakan oleh guru terlebih dahulu. Setelah guru memahami cara kerja media ini, guru diperbolehkan mendemonstrasikan kepada siswa. Demonstrasi yang dilakukan guru diharapkan menggunakan LCD dan layar jika tersedia. Hal ini dilakukan agar seluruh siswa melihat dengan jelas. Jika tidak terdapat fasilitas tersebut guru dapat mendemonstrasikan secara berkelompok. Pada saat guru mendemonstrasikan, siswa mengamati dan bertanya jika dirasa kurang paham. Setelah siswa paham cara kerjanya, siswa boleh memainkannya secara mandiri. Sebelum pembelajaran dimulai guru mengkondisikan kelas sehingga media akan digunakan secara nyaman dan aman oleh siswa. Kemudian guru diharapkan sebelum pembelajaran sudah mempersiapkan media tersebut dalam perangkat keras yang terdapat di sekolahan. Hal ini dilakukan agar tidak menyita waktu saat proses pembelajaran. Bahan ajar yang disiapkan sebelumnya antara lain materi pembelajaran, RPP dan tugas-tugas yang akan dikerjakan oleh siswa. Langkah kelima yaitu melibatkan siswa dalam kegiatan pembelajaran. Tahap ini dilakukan sesuai dengan Rancangan Pelaksanaan Pembelajaran (RPP) yang telah dibuat sebelumnya. Kegiatan yang dilakukan sesuai RPP terdiri dari pendahuluan, inti, dan penutup. Adapun kegiatan pendahuluan guru memberi salam, mengawali dengan doa, melakukan apersepsi, motivasi dan menyampaikan tujuan pembelajaran. Sedangkan pada kegiatan inti guru dan siswa memainkan game yang terdapat materi bangun datar di dalamnya. Kegiatan melibatkan siswa dapat dilakukan pada saat kegiatan inti yaitu dengan memainkan game yang telah dikembangkan. Langkah terakhir dalam model ASSURE yaitu evaluasi dan perbaikan. Saran dan kritik yang diberikan oleh penguji ahli akan digunakan sebagai bahan evaluasi dan perbaikan media pembelajaran yang lebih berkualitas. Media pembelajaran sudah bagus, tetapi terdapat beberapa kritik dan saran yaitu Memperbaiki teknis pengoprasian dan media, memberikan garis putus-putus yang menghubungkan antara sumbu dengan batas batang dalam diagram.

Validasi dilakukan untuk mengetahui kelayakan desain produk $P C$ game. Produk yang telah dinyatakan layak dapat digunakan untuk proses pembelajaran. Validasi oleh pakar materi dan media pembelajaran disajikan pada Tabel 4. 
Tabel 4. Validasi oleh pakar materi dan media pembelajaran

\begin{tabular}{clll}
\hline No & Aspek Validasi & Skor $(\%)$ & Keterangan \\
\hline 1 & Materi Pembelajaran & 78 & Cukup \\
2 & Media Pembelajaran & 81,5 & Baik \\
\hline
\end{tabular}

Berdasarkan data yang dapat dilihat pada Tabel 4 di atas, dapat disimpulkan bahwa materi dalam game termasuk dalam kategori cukup dan baik untuk digunakan dalam proses pembelajaran. Pada aspek materi telah memperhatikan Aspek Materi, Aspek Pembelajaran, Aspek Kebahasaan. Validitas pada aspek ini masih perlu ditingkatkan. Perolehan kategori cukup pada aspek materi berkaitan dengan analisisa kurikulum, perumusan tujuan pembelajaran, kebeneran konsep, kemutakhiran, keseusian contoh, dan aspek bahasa. Aspek materi yang memperoleh skor rendah adalah butir: (1) Kesesuaian materi dengan kompetensi inti (KI) dan kompetensi dasar (KD), (2) Kemutakhiran materi, (3) Urutan penyajian materi, dan (4) Kesesuaian contoh yang diberikan. Pada aspek media diperoleh kategori baik. Ini berkaitan dengan media yang dikembangkan telah mengimplementasikan aspek pemrograman, tampilan, bahasa, dan keprantisan. Aspek pemrograman berkaitan dengan respon program game ketika digunakan oleh siswa. Fitur interaksi game dengan siswa sudah sangat baik. Fitur interaksi dalam game akan memberikan kemudahan kepada siswa (Firmantika \& Mukminan, 2014). Tamplian game juga sudah menarik menggunakan desain latar yang menarik, warna, dan huruf yang sesuai dengan karakteristik siswa. Jenis huruf yang digunakan pade adalah huruf sans serif. Jenis huruf ini memiliki ukuran yang sama pada semua sisinya sehingga dapat dilihat dengan jelas oleh siswa. Tipe huruf sans serif memiliki tebal tipis yang jelas sehingga mudah dilihat (Monica, 2010). Pemanfaatan game memberikan efek kedekatan dengan siswa. Game bagi siswa merupakan hal yang mengasikan sehingga sampai lewat dari batas waktu. Game mampu memberikan kedekatan antara siswa dengan materi yang dipelajari dan kondisi ini dapat memberikan efek lebih baik kepada siswa ketiaka ia menerapkan pengetahuan tersebut (Rey et al., 2019). Selain itu, game yang dikembangkan mampu memberikan suasana senang kepada siswa. Rasa senang dapat memberikan efek positif terhadap motivasi siswa sehingga berdampak terhadap peningkatan outcome pembelajaran (Awan et al., 2019; Perini et al., 2018). Pada game juga disajikan pentujuk memainkan game. Pentujuk yang jelas merupakan salah satu dari aspek desain pembelajaran. Desain pembelajaran yang baik akan membuat siswa belajar secara sistematis dan bermakna sehingga aktivitas belajar siswa berlangsung secara terarah (Az Zafi \& Partono, 2020). Game yang telah dikembangkan menyajikan petunjuk yang jelas sehingga ketika siswa sudah memulai game tidak mengalami kebingunan.

\section{Simpulan}

Berdasarkan pengembangan model media pembelajaran berbasis $P C$ Game untuk meningkatkan kemampuan pemecahan masalah pada materi statistika dapat disimpulkan bahwa pengembangan media pembelajaran berbasis PC Game untuk meningkatkan kemampuan pemecahan masalah pada materi bangun datar dalam validitas materi pada kategori cukup dan validitas media pad kategori baik. Dengan demikian, aspek materi pada media game masih perlu ditingkatkan sehingga dapat dihasilkan media yang efektif dan efisien.

\section{Daftar Pustaka}

Agung, A. A. . (2014). Buku Ajar Metodelogi Penelitian Pendidikan. Aditya Media Publishing.

Awan, O., Dey, C., Salts, H., Brian, J., Fotos, J., Royston, E., Braileanu, M., Ghobadi, E., Powell, J., Chung, C., \& Auffermann, W. (2019). Making Learning Fun: Gaming in Radiology Education. Academic Radiology, 26(8), 1127-1136. https://doi.org/10.1016/j.acra.2019.02.020 
Az Zafi, A., \& Partono, P. (2020). Desain Pembelajaran sebagai Upaya Peningkatan Kualitas Pembelajaran al-Quran Hadis. MATAN: Journal of Islam and Muslim Society, 2(1), 16-25. https://doi.org/https://doi.org/10.20884/1.matan.2020.2.1.2292

Azhar, A. (2011). Media Pembelajaran. Raja Grafindo Persada.

Beck, J. C. (2007). Gamer Juga Bisa Sukses. PT Grasindo.

Firmansyah, M. A. (2017). Analisis Hambatan Belajar Mahasiswa Pada Mata Kuliah Statistika. JPPM, 10(2). http://dx.doi.org/10.30870/jppm.v10i2.2036

Firmantika, L., \& Mukminan. (2014). Pengembangan Media Pembelajaran Berbantuan Komputer untuk Menanamkan Kesadaran Lingkungan Bagi Siswa SMP. Jurnal Harmoni Sosial, 1(2), 155-164. https://doi.org/10.21831/hsjpi.v1i2.2437

Maryati, I. (2017). Analisis Kesulitan Dalam Materi Statistika Ditinjau Dari Kemampuan Penalaran Dan Komunikasi Statistis. Prisma, 6(2), 173-179. https://doi.org/10.35194/jp.v6i2.209

Monica. (2010). Pengaruh Warna, Tipografi, dan Layout pada Situs. Humaniora, 1(2), 459-468. https://doi.org/10.21512/humaniora.v1i2.2887

Novianto, Y., Informatika, T., Dinamika Bangsa, S., JI Jend Sudirman, J., \& -Jambi, T. (2015). Perancangan Game Edukasi Pengenalan Binatang Dan Habitatnya Berbasis Android (Studi Kasus: Tk Ar Ridho Kel.Eka Jaya Jambi). Jurnal IImiah Media Processor, 10(1), 436-443. http://ejournal.stikomdb.ac.id/index.php/processor/article/view/96

Nurdianto, W. B., Juwaedah, A., Studi, P., Tata, P., Kesejahteraan, D. P., \& Pendiidkan, U. (2020). Mahasiswa Pendidikan Tata Boga. Media Pendidikan, Gizi Dan Kuliner, 9(1), 61-64.

Perini, S., Luglietti, R., Margoudi, M., Oliveira, M., \& Taisch, M. (2018). Learning and motivational effects of digital game-based learning (DGBL) for manufacturing education -The Life Cycle Assessment (LCA) game. Computers in Industry, 102, 40-49. https://doi.org/10.1016/j.compind.2018.08.005

Prayudi, K. A. W., Arthana, I. K. R., \& Wirawan, I. M. A. (2015). Pengembangan Game Labrin Matematika Tingkat SD. Kumpulan Artikel Mahasiswa Pendidikan Teknik Informatika, 4(5), 414-421. https://doi.org/http://dx.doi.org/10.23887

Prihatin, E. (2008). Guru sebagai fasilitator. Karsa Mandiri Persada.

Rey, G. D., Beege, M., Nebel, S., Wirzberger, M., Schmitt, T. H., \& Schneider, S. (2019). A Meta-analysis of the Segmenting Effect. In Educational Psychology Review (Vol. 31, Issue 2). Educational Psychology Review. https://doi.org/10.1007/s10648-0189456-4

Rey, G. D., \& Steib, N. (2013). The personalization effect in multimedia learning: The influence of dialect. Computers in Human Behavior, 29(5), 2022-2028. https://doi.org/10.1016/j.chb.2013.04.003

Sadiman, Arief., D. (2006). Media pendidikan. PT Rajagrafindo Persada.

Smaldino, S. E., Lowther, D. L., \& Russell, J. D. (2008). Instructional technology \& media for learning: Teknologi pembelajaran dan media untuk belajar. (Terjemahkan Arif Rahman). Kencana. https://www.pearsonhighered.com/assets/preface/0/1/3/4/0134287525.pdf 